\title{
Parental Resources and Child Abuse and Neglect
}

\author{
By Christina PAXson ANd Jane Waldfogel*
}

A child's welfare is affected not only by the wealth of her parents, but also by the quality of care her parents provide. Physical abuse, neglect, and other forms of child maltreatment impose severe hardships on children and may adversely affect them as adults (Cathy Widom, 1989). We examine whether child maltreatment is affected by the socioeconomic circumstances of parents. Our hypothesis is that children are more likely to be maltreated if their parents have fewer resources. We use a broad conception of "resources." It encompasses not only income, but also parental time and the quality of parental time. For example, a low-income working single mother may be short on resources needed to parent not only because she earns a low income, but also because she may not have the physical or emotional reserves to care for her children properly at the end of the day. Likewise, an unemployed father may provide less than adequate parenting not only because his income has been reduced, but also because of the depression and loss of self-esteem that may accompany unemployment (Arthur Goldsmith et al., 1996).

We use state-level panel data to analyze the impact that socioeconomic circumstances (in particular, parental work status and single parenthood) have on the incidence of child maltreatment. We find that socioeconomic circumstances do matter. States with higher fractions of children with absent fathers, and especially absent fathers and working mothers, have higher rates of child

\footnotetext{
* Paxson: Woodrow Wilson School, Princeton University, Princeton NJ 08544, and NBER; Waldfogel: School of Social Work, Columbia University, New York, NY 10027, and Center for Analysis of Social Exclusion, London School of Economics. We are grateful to the MacArthur Foundation for financial support, to Anne Case, Joanne Gowa, Julie Nelson, and Robert Pollak for useful comments, and to Amanda Lockshin and Yan Jiang for research assistance.
}

maltreatment. Nonworking fathers are also associated with higher rates of maltreatment.

\section{Background}

Child maltreatment is a large and growing problem in the United States. In 1996, over 3 million cases of child abuse and neglect, nearly 50 cases per thousand children, were reported to state child-protective services (CPS) agencies, about a fivefold increase over the number and rate just 20 years earlier (Waldfogel, 1998). The most common type of maltreatment reported to CPS is neglect, which constitutes about 58 percent of all reports. Physical abuse makes up 22 percent of reports. Sexual abuse, emotional maltreatment, and other categories together account for the remaining 20 percent (U.S. Department of Health and Human Services, 1998). About 40 percent of reports are substantiated upon investigation by CPS, and just under 30 percent are kept open for ongoing intervention, which may involve removing the child from home or monitoring the child's safety at home (Waldfogel, 1998).

It has long been noted in the child-abuse literature that children who are poor, have unemployed fathers, or live with single mothers are more likely than others to be reported to CPS (see e.g., David Gil, 1970; Duncan Lindsey, 1994), although it has not been clear whether such children really are more likely to be maltreated or are simply more likely to be reported. There is also evidence from community studies that children living in poor areas are more likely to be identified as maltreated, as are children from communities with higher levels of unemployment or lone parenthood (see Lawrence Steinberg et al., 1981; James Spearly and Michael Lauderdale, 1983; Sheila Ards, 1989; James Garbarino and Kathleen Kostelny, 1992; and Claudia Coulton et al., 1995). However, none of the previous studies has analyzed family structure and parental employment in the kind of detail that we 
use here, and none has analyzed a panel of national data.

\section{Data, Methods, and Results}

Measuring child maltreatment is not a simple task. Direct measures of child maltreatment are difficult to obtain, since interviews with parents or children are unlikely to yield accurate information. Rather than direct information, we use annual information on the numbers of cases of child maltreatment handled by each state's child-protective service agency. However, state-level data have several limitations that one should keep in mind when assessing our results.

One general limitation of using state-level data is that one cannot generalize from statelevel results to individual-level behaviors (this is the "ecological fallacy" problem). If we find, for instance, that states with higher shares of unemployed fathers have higher rates of maltreatment, we cannot conclude from this that unemployed fathers are more likely to abuse their children. This would be one possible explanation for our finding, but not the only one.

A more specific problem is that the statelevel data may not accurately measure the actual amount of child maltreatment. Not all cases of maltreatment are reported, and some reports are not valid. The process of substantiating reports may also be prone to errors: agencies may incorrectly substantiate invalid reports, or not substantiate valid reports. Although in theory the true level of child maltreatment could be greater or less than what state numbers indicate, the general consensus among scholars in this field is that many cases of child maltreatment go unreported and unsubstantiated (Waldfogel, 1998).

Another potential problem is variation across states in how reports of child abuse are handled, and in how data on child abuse are reported. The operations of state childprotective service agencies vary along several dimensions. First, reporting requirements vary across states. For example, states differ in how they define maltreatment and in how they define "mandated reporters" (i.e., those who have a legal responsibility to report suspected maltreatment). Second, states have different standards of evidence required to substantiate a report of child maltreatment as well as different classifications for substantiation decisions. Some states use a two-tier system, in which each report is determined to be either "substantiated" or "unsubstantiated." Other states use a three-tier system which adds the category "indicated," meaning that, although there is good reason to suspect that maltreatment has occurred, the allegation cannot be substantiated to the level of evidence required by state law. Third, states collect and report information on child maltreatment in different ways. For example, some states collect information on the number of families reported for child maltreatment, and some collect information on the number of children reported to be victims of abuse or neglect. For all of these reasons, it is important that our analysis adequately accounts for heterogeneity across states.

The quality of state-level data has improved over time. Between 1976 and 1987, state-level information on reports of child abuse was collected by the Child Protection Division of the American Humane Association. After 1987, this information was collected by the National Committee to Prevent Child Abuse. However, information on the number of substantiated or indicated victims was not uniformly collected by either organization. In 1988, the National Center for Child Abuse and Neglect (NCCAN), the federal agency responsible for assisting states in the prevention and treatment of child maltreatment, was charged with establishing a national clearinghouse for information on child maltreatment. Since 1990 NCCAN has collected and published detailed state-level information on reports of child maltreatment and on numbers of substantiated and indicated victims. Victims are classified by type of maltreatment and by a variety of other variables such as age and sex.

In this paper we use only the 1990-1996 NCCAN data. Although the sample is smaller, there are several advantages of focusing on these years. First, reports of maltreatment are more likely to be accurately measured after NCCAN assumed control of data collection. Second, we can distinguish between reports of maltreatment and the actual number of substantiated victims, and we can disaggregate 
different types of maltreatment. Third, the large increase in reports that characterized the 1970's and 1980's was essentially completed by 1990 . Variations in the measures of maltreatment in the 1990's are more likely to reflect actual changes in the welfare of children, rather than changes in the attention that states focused on the problem of child maltreatment.

We use four measures of child maltreatment. The first is the number of reports. For most states, reports are measured as the number of families reported, so that a family charged with neglecting three children counts as one report. For some states in some years, reports are on a child basis. We use information on the average ratio of child-based to family-based reports (available for a large subset of observations) to convert child-based reports to family-based reports when familybased reports are unavailable. This conversion applied to 20 percent of our sample.

Our second measure is the total number of indicated or substantiated victims. Since not all reports are valid, the number of indicated or substantiated victims may provide a better measure of maltreatment, although this measure may also be affected by a state's willingness to add new cases to the caseload. Our third and fourth measures are the numbers of children who were victims of physical abuse and neglect. In principle, family socioeconomic circumstances may have different effects on these two types of maltreatment. In practice, since some states allow children to be coded as victims of both abuse and neglect, there is some overlap in these two categories and in their models and some double-counting of children in the victim totals.

The socioeconomic variables were constructed from the 1990-1996 rounds of the March Current Population Survey (CPS). These variables reflect the living conditions of children within each state and each year, rather than the living conditions of the entire population. For each year, we selected records for all children under the age of 18 , constructed socioeconomic variables for each child, and then computed estimates of state-level statistics (averages, medians, etc.) across children, using the appropriate individual-level survey weights. The state-level statistics include the median of the logarithm of the child's house- hold per capita income, the fraction of children living in urban areas, the fraction of children who are white, black, or of another race, the fraction of children with an employed mother, the fraction with a nonworking father, and the fraction with no father in the household. (We restricted our sample to children with a mother in the household; see the following discussion of how "mother" is defined.) We also constructed more detailed measures of parental presence and work status. These show the fraction of children in each of six categories, which represent all the combinations of the mother's work status with the father's status: two working parents (48.1 percent of our sample), nonworking mother and working father (23.5 percent), working mother and no father (10.9 percent), nonworking mother and no father (7.9 percent), working mother and nonworking father (5.1 percent), and two nonworking parents ( 4.5 percent).

Our definitions of "mother" and "father" require discussion. Ideally, we would like to distinguish between children who live with biological and nonbiological parents. This is potentially important, given evidence that nonbiological parents (stepparents or cohabitants of the parent) are more likely to abuse children (Martin Daly and Margo Wilson, 1996). However, the CPS does not permit such fine distinctions. For our purposes, "father" is broadly defined to include biological fathers (who may or may not be married to the mother), stepfathers, adoptive fathers, and live-in boyfriends who are not biological fathers. Likewise, "mothers" can be biological mothers, stepmothers, or adoptive mothers.

The state-level aggregates from the CPS were merged with the state-level information from NCCAN on child maltreatment, and information on the number of children in each state was obtained from Bureau of the Census publications. Our final data set consists of 320 observations from 1990-1996, representing all states except West Virginia and Maryland (which did not report all variables to NCCAN), plus the District of Columbia, for an average of 6.5 years per state.

Our task is to estimate the relationships between the socioeconomic variables and the measures of child maltreatment. One of our primary concerns is that the state-level socio- 
economic variables may be correlated with unobserved factors that also influence child maltreatment. An obvious problem is that the upward trend in reports of child maltreatment may be spuriously correlated with trends in other variables, such as the rate of labor-force participation of mothers and the general increase in income levels. To the extent that these trends are common across states, this problem is easily handled with the addition of a set of year effects. A more serious problem is that there may be other factors that affect child maltreatment, such as the resources put into a state's child protective-service agency or the cost of child care in a state, that are unobserved but correlated with other observed variables, resulting in biased parameter estimates. To the extent that these factors are fixed over time within states, this problem can be remedied through the introduction of a set of state-specific fixed effects. However, the use of fixed effects comes at a cost, in that it removes the cross-state variation in the data that can help us identify the effects in which we are interested, and it will also exacerbate attenuation bias due to measurement error in the independent variables.

Attenuation bias is especially likely to be a problem, since the independent variables constructed from the CPS are estimates of statelevel variables, rather than their true values, and thus are subject to sampling error. Fortunately, this form of measurement error can be corrected. As shown in Angus Deaton (1985), the bias in the parameter estimates is a function of the variances and covariances of the state-level means constructed from the CPS. These variances and covariances can be estimated from the micro data and used to adjust the parameter estimates for bias. We follow the methods described in Deaton (1985), treating all variables constructed from the CPS, with the exception of the median of the logarithm of income, as noisy estimates of true state values. This correction has a substantial effect on the parameter estimates: many of the ordinary least-squares (OLS) coefficients increased (in absolute value) by 25 percent; the fixed-effects estimates often doubled.

Tables 1 and 2 present regression results. The dependent variables in both tables are the logarithms of the four measures of child mal-
Table 1-Determinants of Child Maltreatment

\begin{tabular}{|c|c|c|c|c|}
\hline \\
\hline \multirow{2}{*}{$\begin{array}{l}\text { Independent } \\
\text { variable }\end{array}$} & \multicolumn{2}{|c|}{$\ln$ (Reports) } & \multicolumn{2}{|c|}{$\ln$ (Victims) } \\
\hline & No FE & $\mathrm{FE}$ & No $\mathrm{FE}$ & $\mathrm{FE}$ \\
\hline $\ln ($ Kids $<18)$ & $\begin{array}{r}0.951 \\
(38.21)\end{array}$ & $\begin{array}{c}0.322 \\
(1.16)\end{array}$ & $\begin{array}{r}0.933 \\
(21.85)\end{array}$ & $\begin{array}{c}2.382 \\
(4.02)\end{array}$ \\
\hline $\begin{array}{l}\ln \text { (Median income } \\
\text { per capita) }\end{array}$ & $\begin{array}{c}-0.521 \\
(3.46)\end{array}$ & $\begin{array}{r}0.182 \\
(1.43)\end{array}$ & $\begin{array}{c}-0.610 \\
(2.36)\end{array}$ & $\begin{array}{r}0.347 \\
(1.28)\end{array}$ \\
\hline Urban & $\begin{array}{r}0.237 \\
(1.78)\end{array}$ & $\begin{array}{c}-0.119 \\
(1.84)\end{array}$ & $\begin{array}{r}0.373 \\
(1.64)\end{array}$ & $\begin{array}{r}-0.141 \\
(1.02)\end{array}$ \\
\hline Black & $\begin{array}{c}-0.818 \\
(2.60)\end{array}$ & $\begin{array}{r}0.451 \\
(0.66)\end{array}$ & $\begin{array}{r}-0.901 \\
(1.67)\end{array}$ & $\begin{array}{r}-1.347 \\
(0.91)\end{array}$ \\
\hline Other race & $\begin{array}{c}-1.470 \\
(4.83)\end{array}$ & $\begin{array}{c}-0.741 \\
(0.83)\end{array}$ & $\begin{array}{c}-1.005 \\
(1.92)\end{array}$ & $\begin{array}{r}-3.077 \\
(1.61)\end{array}$ \\
\hline Working mom & $\begin{array}{r}0.801 \\
(1.64)\end{array}$ & $\begin{array}{r}0.019 \\
(0.05)\end{array}$ & $\begin{array}{r}1.639 \\
(1.96)\end{array}$ & $\begin{array}{c}0.088 \\
(0.11)\end{array}$ \\
\hline No dad & $\begin{array}{r}1.949 \\
(2.65)\end{array}$ & $\begin{array}{r}1.214 \\
(2.40)\end{array}$ & $\begin{array}{l}4.388 \\
(3.47)\end{array}$ & $\begin{array}{r}2.789 \\
(2.57)\end{array}$ \\
\hline Nonworking dad & $\begin{array}{r}3.064 \\
(3.87)\end{array}$ & $\begin{array}{r}1.923 \\
(3.08)\end{array}$ & $\begin{array}{r}5.849 \\
(4.31)\end{array}$ & $\begin{array}{l}2.928 \\
(2.21)\end{array}$ \\
\hline
\end{tabular}

B.

\begin{tabular}{lccccc} 
& \multicolumn{2}{c}{$\begin{array}{c}\text { In(Victims of } \\
\text { physical abuse) }\end{array}$} & & \multicolumn{2}{c}{$\begin{array}{c}\text { In(Victims of } \\
\text { neglect) }\end{array}$} \\
\cline { 2 - 3 } \cline { 6 - 6 } $\begin{array}{l}\text { Independent } \\
\text { variable }\end{array}$ & No Fe & FE & & No FE & FE \\
\hline In(Kids $<18)$ & 0.934 & 3.293 & & 0.896 & 4.005 \\
& $(24.27)$ & $(5.73)$ & & $(14.89)$ & $(4.57)$ \\
In(Median income & -0.500 & 0.606 & & -0.663 & -0.200 \\
per capita) & $(2.15)$ & $(2.30)$ & & $(1.82)$ & $(0.50)$ \\
Urban & 0.160 & -0.024 & & 0.159 & 0.045 \\
& $(0.78)$ & $(0.18)$ & & $(0.49)$ & $(0.22)$ \\
Black & -1.741 & 1.403 & & -0.634 & -1.624 \\
& $(3.59)$ & $(0.98)$ & & $(0.84)$ & $(0.74)$ \\
Other race & -1.156 & -4.142 & & -2.292 & -3.078 \\
& $(2.45)$ & $(2.23)$ & & $(3.11)$ & $(1.09)$ \\
Working mom & 0.617 & -0.358 & & 3.329 & 0.986 \\
& $(0.82)$ & $(0.47)$ & $(2.82)$ & $(0.85)$ \\
No dad & 3.230 & 2.332 & & 5.811 & 1.963 \\
& $(2.84)$ & $(2.23)$ & $(3.26)$ & $(1.24)$ \\
Nonworking dad & 5.809 & 1.979 & & 7.278 & 1.853 \\
& $(4.75)$ & $(1.55)$ & $(3.81)$ & $(0.96)$ \\
\hline
\end{tabular}

Notes: Year dummies included in all regressions. Absolute $t$ statistics are reported in parentheses. The columns labeled "no FE" do not include state fixed effects, and the columns labeled "FE'" do.

treatment. We show specifications with two sets of independent variables. Both include a set of year dummies, the logarithm of the number of children in the state, the fraction of children who are urban, black, or other nonwhite race, and the logarithm of median household income per capita. The specifications differ in the level of detail of the measures of the home environment. The first, in Table 1, includes the fraction of children with mothers who work, the fraction of children with absent fathers, 
Table 2-Detalled Determinants of Child MALTREATMENT

\begin{tabular}{|c|c|c|c|c|}
\hline \\
\hline \multirow{2}{*}{$\begin{array}{l}\text { Independent } \\
\text { variable }\end{array}$} & \multicolumn{2}{|c|}{$\ln ($ Reports) } & \multicolumn{2}{|c|}{$\ln ($ Victims $)$} \\
\hline & No FE & FE & No FE & FE \\
\hline $\begin{array}{l}\ln (\text { Median income } \\
\text { per capita) }\end{array}$ & $\begin{array}{c}-0.488 \\
(3.09)\end{array}$ & $\begin{array}{c}0.173 \\
(1.31)\end{array}$ & $\begin{array}{r}-0.513 \\
(1.89)\end{array}$ & $\begin{array}{r}0.459 \\
(1.55)\end{array}$ \\
\hline $\begin{array}{l}\text { Nonworking mom, } \\
\text { no dad }\end{array}$ & $\begin{array}{c}0.315 \\
(0.32)\end{array}$ & $\begin{array}{r}1.161 \\
(1.74)\end{array}$ & $\begin{array}{r}2.804 \\
(1.66)\end{array}$ & $\begin{array}{r}0.807 \\
(0.54)\end{array}$ \\
\hline $\begin{array}{l}\text { Mom works, no } \\
\text { dad }\end{array}$ & $\begin{array}{l}4.525 \\
(3.19)\end{array}$ & $\begin{array}{l}1.170 \\
(1.64)\end{array}$ & $\begin{array}{c}8.108 \\
(3.31)\end{array}$ & $\begin{array}{r}4.259 \\
(2.63)\end{array}$ \\
\hline $\begin{array}{l}\text { Nonworking mom, } \\
\text { nonworking dad }\end{array}$ & $\begin{array}{l}2.078 \\
(1.13)\end{array}$ & $\begin{array}{r}1.367 \\
(1.29)\end{array}$ & $\begin{array}{r}8.222 \\
(2.59)\end{array}$ & $\begin{array}{r}6.344 \\
(2.58)\end{array}$ \\
\hline $\begin{array}{l}\text { Mom works, } \\
\text { nonworking dad }\end{array}$ & $\begin{array}{r}4.247 \\
(2.25)\end{array}$ & $\begin{array}{r}2.287 \\
(2.36)\end{array}$ & $\begin{array}{l}5.063 \\
(1.56)\end{array}$ & $\begin{array}{c}0.142 \\
(0.07)\end{array}$ \\
\hline $\begin{array}{l}\text { Mom works, dad } \\
\text { works }\end{array}$ & $\begin{array}{l}0.058 \\
(0.10)\end{array}$ & $\begin{array}{r}-0.115 \\
(0.25)\end{array}$ & $\begin{array}{r}1.414 \\
(1.49)\end{array}$ & $\begin{array}{r}-0.420 \\
(0.41)\end{array}$ \\
\hline
\end{tabular}

B.

\begin{tabular}{lccccc} 
& \multicolumn{2}{c}{$\begin{array}{l}\ln (V i c t i m s \\
\text { physical abuse) }\end{array}$} & & \multicolumn{2}{c}{$\begin{array}{c}\text { In(Victims of } \\
\text { neglect) }\end{array}$} \\
\cline { 2 - 3 } \cline { 6 - 6 } $\begin{array}{l}\text { Independent } \\
\text { variable }\end{array}$ & No FE & FE & & No FE & FE \\
\hline In(Median income & -0.386 & 0.753 & & -0.472 & -0.041 \\
$\quad$ per capita) & $(1.58)$ & $(2.46)$ & & $(1.23)$ & $(0.09)$ \\
Nonworking mom, & 2.057 & -0.707 & & 2.993 & -1.285 \\
$\quad$ no dad & $(1.35)$ & $(0.45)$ & & $(1.25)$ & $(0.58)$ \\
Mom works, no & 5.679 & 4.012 & & 12.953 & 5.077 \\
$\quad$ dad & $(2.58)$ & $(2.42)$ & & $(3.75)$ & $(2.16)$ \\
Nonworking mom, & 9.641 & 6.032 & & 12.380 & 6.507 \\
$\quad$ nonworking dad & $(3.37)$ & $(2.34)$ & & $(2.77)$ & $(1.84)$ \\
Mom works, & 2.844 & -2.066 & & 5.380 & -1.341 \\
$\quad$ nonworking dad & $(0.97)$ & $(0.92)$ & & $(1.17)$ & $(0.42)$ \\
Mom works, dad & 0.751 & -1.394 & & 3.056 & -0.018 \\
$\quad$ works & $(0.88)$ & $(1.31)$ & & $(2.28)$ & $(0.01)$ \\
\hline
\end{tabular}

Notes: See notes to Table 1. Year dummies, the logarithm of children in the state, and the fractions of children who are urban, black, and other (nonwhite) races are included in all regressions.

and the fraction of children with present but nonworking fathers. The second, in Table 2, includes the more detailed set of measures of the mother's and father's status. (The coefficients for the population, urbanization, and race variables are not reported in Table 2 . They are very similar to those shown in Table 1.)

The main lesson to be drawn from Tables 1 and 2 is that parental work status and singleparenthood affect child maltreatment. The results in Table 1 indicate that higher fractions of children living with working mothers, no fathers, or nonworking fathers are associated with more reports of maltreatment, more substantiated reports, and more cases of physical abuse and neglect. The effect of working mothers on maltreatment becomes insignificant when fixed effects are included, but the effects of the status of fathers stay significant and large. For example, the fixed effects imply that, all else equal, if the fraction of children living with no father were to increase from 0.10 (the average value for Utah in 1990-1996) to 0.30 (the average for Mississippi), the number of victims of child maltreatment would rise by 56 percent. The effects of more children with nonworking fathers are extremely similar to the effects of more children with absent fathers. It is interesting that the fixed-effects estimates of father's status are significant for the total number of victims and the number of victims of physical abuse, but insignificant for neglect.

The results in Table 2 provide a more detailed picture of the relationship between home environment and maltreatment, and they highlight the idea that there are interactions between the mother's and father's status. There are several key results. First, the adverse effect of absent fathers, seen in Table 1, is only present when the mother works. The fraction of children with nonworking mothers and absent fathers has no effect on maltreatment (relative to the omitted category of children with a nonworking mother and a working father). However, the combination of absent fathers and working mothers appears to be particularly harmful, with large and significant effects on total maltreatment as well as both physical abuse and neglect. Second, the adverse effects of two nonworking parents are large and significant, although the effects of working mothers and nonworking fathers are generally insignificant. Third, higher fractions of two working parents do not appear to be harmful. In general, higher fractions of children with two parents in the household, at least one of whom is working, result in less maltreatment.

In alternative models not shown here, we added controls for the number of women and men arrested for drug use by state and year, using data from the FBI's Uniform Crime Reports. We found, as have other researchers (see e.g., Vicky Albert and Richard Barth, 1996; Sara Markowitz and Michael Grossman, 1998), that there is a positive relationship between substance abuse and child maltreatment, but this relationship did not hold up in 
the fixed-effects models. Controlling for drug arrests did not affect our estimates of the effects of family structure or employment.

Our results for income are less conclusive. Although we find the expected negative effects of median per capita income on the number of reports and number of victims in the models with no state fixed effects, these effects do not hold up in the fixed-effects estimates. Controlling for poverty or mean income (or both) yields similar results. It may be that our panel is too short to allow us to estimate income effects in a fixed-effects model; in other estimates (not shown here), using data from a longer time series (1977-1996), we do find a negative effect of income on reports even in fixed-effects models. This is clearly an area that merits further work.

\section{Conclusion}

Using state-level panel data, we find that socioeconomic circumstances (in particular, parental work status and single parenthood) affect the incidence of child maltreatment. States with higher fractions of children with absent fathers, and especially those with absent fathers and working mothers, have higher rates of child maltreatment, as do states with higher shares of nonworking fathers. We also find some evidence that states with higher incomes have lower rates of child abuse and neglect, although this result was sensitive to specification. Our work adds to the growing literature that relates economic circumstances to child well-being. Our results also have implications for the effects on children of welfare reforms that move single parents into the labor force without substantially increasing their incomes.

\section{REFERENCES}

Albert, Vicky and Barth, Richard. "Predicting Growth in Child Abuse and Neglect Reports in Urban, Suburban, and Rural Counties." Social Service Review, March 1996, 70(1), pp. $58-82$.

Ards, Sheila. "Estimating Local Child Abuse." Evaluation Review, October 1989, 13(5), pp. 484-515.

$\rightarrow$ Coulton, Claudia; Korbin, Jill; Su, Marilyn and Chow, Julian. "Community Level Factors and Child Maltreatment Rates." Child Development, October 1995, 66(5), pp. 126276.

$\rightarrow$ Daly, Martin and Wilson, Margo. "Violence Against Step-Children.' Current Direc. tions in Psychological Science, June 1996, 5(3), pp. 77-81.

Deaton, Angus. 'Panel Data from Time Series of Cross-Sections." Journal of Econometrics, October-November 1985, 30(1-2), pp. 109-26.

Garbarino, James and Kostelny, Kathleen. "Child Maltreatment as a Community Problem.' Child Abuse and Neglect, JulyAugust 1992, 16(4), pp. 455-64.

Gil, David. Violence against children. Cambridge, MA: Harvard University Press, 1970.

Goldsmith, Arthur; Veum, Jonathan and Darity, William. "The Psychological Impact of Unemployment and Joblessness.' Journal of Socio-economics, 1996, 25(3), pp. 33358.

Lindsey, Duncan. The welfare of children. New York: Oxford University Press, 1994.

Markowitz, Sara and Grossman, Michael. ${ }^{6 \mathrm{Al}-}$ cohol Regulation and Violence Toward Children." National Bureau of Economic Research (Cambridge, MA) Working Paper No. 6359, 1989.

Spearly, James and Lauderdale, Michael. " Community Characteristics and Ethnicity in the Prediction of Child Maltreatment Rates." Child Abuse and Neglect, 1983, 7(1), pp. 91-105.

$\rightarrow$ Steinberg, Lawrence; Catalano, Ralph and Dooley, David. "'Economic Antecedents of Child Abuse and Neglect." Child Development, September 1981, 52(3), pp. 97585.

U.S. Department of Health and Human Services, National Center for Child Abuse and Neglect. Child maltreatment 1996. Washington, DC: U.S. Government Printing Office, 1998.

Waldfogel, Jane. The future of child protection . Cambridge, MA: Harvard University Press, 1998.

$\rightarrow$ Widom, Cathy. "The Cycle of Violence." Science, 4 April 1989, 244(14), pp. 16066. 